\title{
Impact of elevation and weather patterns on the isotopic composition of precipitation in a tropical montane rainforest
}

\author{
D. Windhorst ${ }^{1}$, T. Waltz ${ }^{1}$, E. Timbe ${ }^{2}$, H.-G. Frede ${ }^{1}$, and L. Breuer ${ }^{1}$ \\ ${ }^{1}$ Institute for Landscape Ecology and Resources Management (ILR), Research Centre for BioSystems, \\ Land Use and Nutrition (IFZ), Justus-Liebig-Universität Gießen, Gießen, Germany \\ ${ }^{2}$ Grupo de Ciencias de la Tierra y del Ambiente, DIUC, Universidad de Cuenca, Cuenca, Ecuador
}

Correspondence to: D. Windhorst (david.windhorst@umwelt.uni-giessen.de)

Received: 12 June 2012 - Published in Hydrol. Earth Syst. Sci. Discuss.: 10 July 2012

Revised: 20 December 2012 - Accepted: 21 December 2012 - Published: 31 January 2013

Abstract. This study presents the spatial and temporal variability of $\delta^{18} \mathrm{O}$ and $\delta^{2} \mathrm{H}$ isotope signatures in precipitation of a south Ecuadorian montane cloud forest catchment (San Francisco catchment). From 2 September to 25 December 2010 , event sampling of open rainfall was conducted along an altitudinal transect (1800 to $2800 \mathrm{~m}$ a.s.l.) to investigate possible effects of altitude and weather conditions on the isotope signature.

The spatial variability is mainly affected by the altitude effect. The event based $\delta^{18} \mathrm{O}$ altitude effect for the study area averages $-0.22 \% \circ \times 100 \mathrm{~m}^{-1}\left(\delta^{2} \mathrm{H}:-1.12 \% \circ \times 100 \mathrm{~m}^{-1}\right)$. The temporal variability is mostly controlled by prevailing air masses. Precipitation during the times of prevailing southeasterly trade winds is significantly enriched in heavy isotopes compared to precipitation during other weather conditions. In the study area, weather during austral winter is commonly controlled by southeasterly trade winds. Since the Amazon Basin contributes large amounts of recycled moisture to these air masses, trade wind-related precipitation is enriched in heavy isotopes. We used deuterium excess to further evaluate the contribution of recycled moisture to precipitation. Analogously to the $\delta^{18} \mathrm{O}$ and $\delta^{2} \mathrm{H}$ values, deuterium excess is significantly higher in trade wind-related precipitation. Consequently, it is assumed that evaporated moisture is responsible for high concentrations of heavy isotopes during austral winter.

\section{Introduction}

Stable water isotopes have been widely used as tracers in catchment hydrology, e.g. to validate hydrological models (Birkel et al., 2009; Koivusalo et al., 2000; Liebminger et al., 2007; Rodgers et al., 2005b), identify areas of groundwater recharge (Cortés et al., 1997; Gonfiantini et al., 2001; Kattan, 2006), investigate flow paths (Barthold et al., 2011; Goller et al., 2005; Rodgers et al., 2005a) or to calculate the mean transit time (MTT) of water (Garvelmann et al., 2012; Kabeya et al., 2007; McGuire et al., 2002, 2005; Rodgers et al., 2005b).

All these approaches require a detailed knowledge of the composition of the isotopic input signal, i.e. precipitation (Darling and Talbot, 2003). However, the isotopic composition of this precipitation signal varies temporally and spatially due to the depletion of isotopes caused by the temperature, amount (or rainout), continental, elevation (or altitude) and prevailing weather conditions, mostly expressed by a seasonal effect (Dansgaard, 1964; Gat, 1996; Siegenthaler and Oeschger, 1980). On catchment scales, the altitude effect is an important measure for the spatial variability, especially in mountainous catchments that cover high altitudinal ranges. It has therefore been the topic of various studies conducted around the world (Cortés et al., 1997; Garcia et al., 1998; Gonfiantini et al., 2001; Kattan, 2006; McGuire et al., 2005; Peng et al., 2010; Scholl et al., 2009; Siegenthaler and Oeschger, 1980; Vimeux et al., 2005, 2011; Vogel et al., 1975; Yurtsever and Gat, 1981). Most of the reported lapse rates for $\delta^{18} \mathrm{O}$ and $\delta^{2} \mathrm{H}$ lie in ranges of -0.1 to $-0.6 \% \circ \times 100 \mathrm{~m}^{-1}$ and -0.5 to $-4 \% \circ \times 100 \mathrm{~m}^{-1}$, 
respectively. The altitude effect is usually less pronounced in the tropics (Sturm et al., 2007) though information for tropical montane rainforest ecosystems is limited. We are aware of only one study in Puerto Rico where a gradient of $-0.12 \% \circ \times 100 \mathrm{~m}^{-1}$ for $\delta^{18} \mathrm{O}$ and $-0.6 \% \circ \times 100 \mathrm{~m}^{-1}$ for $\delta^{2} \mathrm{H}$ has been found (Scholl et al., 2009).

In addition to the altitudinal effect, the temporal variability of isotope signatures in precipitation can be substantial. In many ecosystems a clear seasonality is observed, which is attributable to the amount effect, with precipitation being depleted in heavy isotopes during wet seasons (Dansgaard, 1964; Garcia et al., 1998; Gonfiantini et al., 2001; Lachniet and Patterson, 2006, 2009; Liu et al., 2007; Rietti-Shati et al., 2000; Rozanski et al., 1992), though seasonal differences tend to be smaller in the tropics than at higher latitudes (Scholl et al., 2011). In general, the isotopic composition of the incoming precipitation is inherently shaped by its history, e.g. by the source of the moisture and the amount effect due to rainout along the path taken by the air mass. As we cannot distinguish between the factors shaping the history of the incoming air mass by looking at on-site measurements, we restricted our analysis to the dependency of the isotopic signature of the precipitation on the prevailing weather conditions, the source of the incoming air masses, the spatial dependency within the study area and the on-site amount effect due to a discrimination of light isotopes during rainout in the course of a single event. For the on-site amount effect we assume that events with a higher amount of precipitation and the same history will yield an overall lighter isotopic composition than events with smaller amounts of rainfall. However, recent studies give rise to the assumption that factors other than the amount of precipitation or the origin of the air masses play an important role in controlling seasonal patterns of isotope signatures (Breitenbach et al., 2010; Feng et al., 2009; Kebede and Travi, 2011; Lee et al., 2009; Peng et al., 2010; Rhodes et al., 2006; Risi et al., 2008a,b; Scholl et al., 2009; Villacís et al., 2008; Vimeux et al., 2005, 2011). For example, Rhodes et al. (2006) and Scholl et al. (2009) concluded that orographic precipitation during the trade wind dominated dry season is enriched compared to the mostly convective precipitation type during the wet season occurring, e.g. in Costa Rica and Puero Rico, respectively. Vimeux et al. (2005) reported that moisture transport history is another important factor controlling the seasonal variation of isotope signatures in the Andes. The Amazon Basin is known to contribute large amounts of recycled moisture to the air masses transported by trade winds (Martinelli et al., 1996; Salati et al., 1979; Valletcoulomb et al., 2008). This contribution of recycled moisture to precipitation can be traced by the deuterium excess parameter (Araguas-Araguas et al., 2000; Froehlich et al., 2002; Gat, 2000; Kabeya et al., 2007; Njitchoua et al., 1999; Victoria et al., 1991). Since southeasterly (SE) trade winds prevail in our research area in the tropical montane forests of southern Ecuador during austral winter (Emck, 2007), we assume that a large share of the air masses responsible for rainfall during this period originates from the Amazon. Consequently, we expect higher isotope signatures and higher values of deuterium excess during the period dominated by SE trade winds.

Our work focuses on improving the understanding of the hydrological processes responsible for the rainfall-runoff generation in a remote tropical montane rainforest catchment of Ecuador. Previous work in micro-catchments in the study area by Goller et al. (2005) focused on the temporal variability of isotope signatures in rainfall, throughfall, and stream water. They found that near-surface event water dominates runoff in these pristine rainforest-covered micro-catchments. In contrast, groundwater dominated fluxes tend to govern runoff generation on larger scales as revealed by geogenic tracer analyses (Bücker et al., 2010; Crespo et al., 2012). Surprisingly, Crespo et al. (2012) derived MTTs of up to 260 to 350 days, despite the very responsive, flashy hydrographs that tend to react within a few hours to precipitation inputs. The uncertainty of this estimate remains unknown, given the limited information of stable isotopes in precipitation that the authors used.

This study presents a more detailed investigation of the temporal and spatial variations in $\delta^{18} \mathrm{O}$ and $\delta^{2} \mathrm{H}$ isotope signatures of precipitation and paves the ground for further research. As a monitoring period of around 3 months is not sufficient to identify the seasonality in the isotopic compositions of precipitation, we rather investigate the dependency of isotopic composition on weather conditions and the origin of air masses responsible for the rainfall. However, origin of air masses goes along with a change in seasons in our research area (Bendix et al., 2008) and thus can be seen as a proxy for seasonality. The identification of processes causing the variation in the isotopic composition will establish a tool for understanding the interdependencies among climate, hydrology, ecology and water resources in future research (Rhodes et al., 2006). Knowledge about the spatial variability of isotope signatures in precipitation will enable researchers to better identify flow paths and draw conclusions about the contribution of precipitation from different altitudes to discharge (Cortés et al., 1997; Gonfiantini et al., 2001; Kattan, 2006). Tracing isotopes through the hydrological cycle further allows calculations of the MTT in the catchment. The objective of this paper therefore is to investigate the following hypotheses, which are based on findings reported in the preceding section:

1. The concentration of heavy isotopes decreases with increasing altitude.

2. Precipitation during SE trade wind-dominated periods is enriched in heavy isotopes compared to precipitation during other weather conditions.

3. Precipitation during SE trade wind-dominated periods shows significantly higher deuterium excess values. 


\section{Material and methods}

\subsection{Location and climate of the study area}

The study area is located on the eastern slopes of the Andes (S Ecuador) in the San Francisco valley. As part of the Amazon Basin, close to the border of the watershed, the terrain of the region surrounding the study area is characterized by a more or less continuous decline to the east and a comparatively high mountain range to the west. The highest point of the study area is the Cerro El Consuelo, colloquial Antenas, at $3155 \mathrm{~m}$ a.s.1. The lowest point is at $1720 \mathrm{~m}$ a.s.1. Figure 1 shows the topography of the study area and the location of sampling sites and climate stations. The topography of the San Francisco catchment allows the investigation of a large altitudinal gradient within a relatively small horizontal distance. Valleys in the study area are deeply incised. The southern part of the catchment is mainly vegetated by primary forest. In the northern part, the natural forest has been replaced by extensive pastures in parts and is further characterized by a mix of shrubs, reforestation sites and sub-paramo (Göttlicher et al., 2009).

Average annual sums of precipitation, for the period 2002 to 2008 , amount to 1500 to $4900 \mathrm{~mm} \mathrm{a}^{-1}$ with a large spatial variability (Rollenbeck and Bendix, 2011). Moreover, there is a significant input of fog to the ecosystem, which accounts for 5 to $35 \%$ of precipitation and enhances the total water input up to $6500 \mathrm{~mm} \mathrm{a}^{-1}$ at the highest altitudes (Rollenbeck et al., 2011). According to Rollenbeck et al. (2011) the designated fog input increases with altitude and amount of rainfall, comprising various forms of horizontal precipitation like the actual fog, drizzle and other wind driven rain. Along a $\mathrm{N}$ to $\mathrm{S}$ transect investigated by Bendix et al. (2008), an altitudinal increase of precipitation (lapse rate) of $220 \mathrm{~mm} \times 100 \mathrm{~m}^{-1}$ was observed. However, spatial observations of radar-based precipitation inputs do not indicate that this altitudinal effect is valid for the whole study area, especially in an E-W direction (Rollenbeck and Bendix, 2011). Along the $\mathrm{E}-\mathrm{W}$ transect that was investigated in the present study (Fig. 1), climate stations have also not shown an altitudinal increase of incoming precipitation. Precipitation at the highest point investigated in this study (El Tiro, $2800 \mathrm{~m}$ a.s.l.) amounts to $1500 \mathrm{~mm} \mathrm{a}^{-1}$, whilst at the lowest point (ECSF, $1800 \mathrm{~m}$ a.s.l.) it is $2176 \mathrm{~mm} \mathrm{a}^{-1}$ (Bendix et al., 2006; Emck, 2007). This demonstrates the high spatial variability of precipitation amounts occurring in the study area.

The weather within the study area is dominated by easterly trade winds. From January to April, northeasterly trade winds are prevailing. Southeasterly trade winds dominate weather in the study area from April to mid-October (Emck, 2007). From June to September, the proportion of trade winds is close to $100 \%$. For the rest of the year, it is still more than $50 \%$. The temporal variability of isotope signatures in the present study was, for the most part, expected to be determined by the prevailing air masses. During the investigation

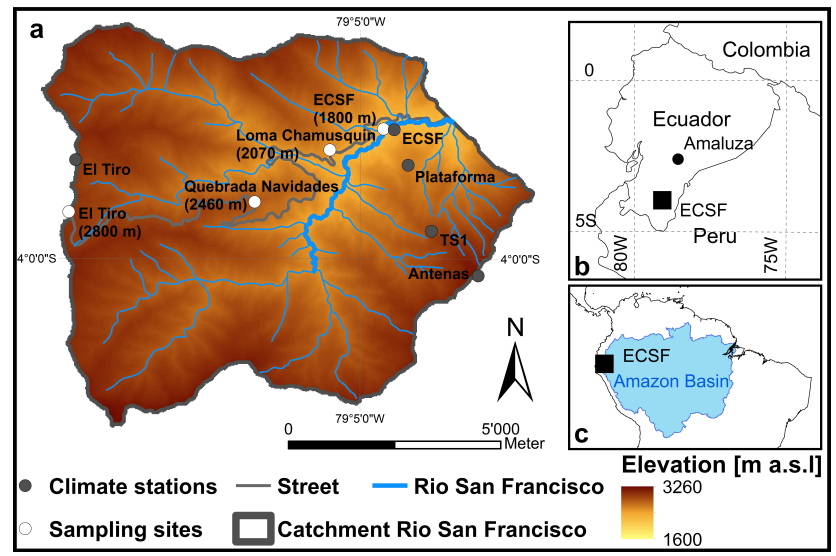

Fig. 1. (a) Investigation area with sampling sites, climate stations and (b) location of the study area within Ecuador and (c) within South America.

period, southeasterly tropical trade winds were prevailing from September to mid-October. In that period, wind direction was hardly changing and wind speeds were high (5 to $15 \mathrm{~m} \mathrm{~s}^{-1}$ ). From mid-October on, as trade winds weakened, wind direction was much less clear defined and lower wind speeds were measured. The observed change in weather patterns at that time of the year is consistent with long-term climate records for the study area (Bendix et al., 2008; Emck and Richter, 2008). Since tropical trade winds travel at altitudes below $3000 \mathrm{~m}$ (Scholl et al., 2002), the Andes form a topographic barrier which leads to a rainout of air masses. The Cordillera Real serves as a climate divide between the humid Amazon Basin and the dry inter-Andean region. From mid-October on, when trade winds weaken in their intensity and frequency, other wind directions and lower wind speeds are observed. However, precipitation originating from Pacific westerlies hardly reaches the study area, since most of these air masses rainout at the western slopes of the Andes (Bendix et al., 2008; Emck, 2007).

The main factor influencing air temperature in the study area is elevation. Mean annual temperature ranges from $12{ }^{\circ} \mathrm{C}$ (at $3260 \mathrm{~m}$ a.s.1.) to $22^{\circ} \mathrm{C}$ (at $1600 \mathrm{~m}$ a.s.l.). The average gradient of air temperature is $0.61^{\circ} \mathrm{C} \times 100 \mathrm{~m}^{-1}$. As usual for tropical regions, seasonal changes in temperature are low (Bendix et al., 2008).

\subsection{Experimental set-up}

To investigate depletion effects on isotope signatures in precipitation, a transect along an altitudinal gradient of $1000 \mathrm{~m}$ was investigated. An event sampling was conducted at four sampling sites along this altitudinal gradient: ECSF at 1800 ma.s.l., Loma Chamusquín at 2070 m a.s.l., Quebrada Navidades at $2460 \mathrm{~m}$ a.s.l. and El Tiro at 2800 m a.s.l. (Fig. 1). 
Table 1. Results of the validation experiment. Temperature and relative humidity during the validation experiment. Day- and night-time temperatures were programmed in 12-h cycles.

\begin{tabular}{lcccrcrc}
\hline Scenario & $\begin{array}{c}\text { Daytime } \\
\text { temperature } \\
{\left[{ }^{\circ} \mathrm{C}\right]}\end{array}$ & $\begin{array}{c}\text { Night-time } \\
\text { temperature } \\
{\left[{ }^{\circ} \mathrm{C}\right]}\end{array}$ & $\begin{array}{c}\text { Relative } \\
\text { humidity } \\
{[\%]}\end{array}$ & $\begin{array}{r}\text { Slope } \\
\delta^{2} \mathrm{H} \\
{\left[\% \circ \mathrm{d}^{-1}\right]}\end{array}$ & $\begin{array}{r}\text { Slope } \\
\delta^{18} \mathrm{O}\end{array}$ & $p$ \\
\hline 1 & 30 & 15 & 50 & 0.031 & 0.084 & 0.044 & 0.796 \\
2 & 30 & 15 & 90 & -0.013 & 0.697 & 0.135 & 0.171 \\
3 & 15 & 10 & 50 & -0.037 & 0.529 & -0.12 & 0.098 \\
4 & 15 & 10 & 90 & 0.025 & 0.354 & 0.024 & $0.029 *$ \\
\hline
\end{tabular}

* Denotes that the regression is significant on the 0.05 level.

Each site consisted of three collectors made from $1 \mathrm{~L}$ glass bottles prepared with circular funnels of $0.10 \mathrm{~m}$ in diameter. Bottles were placed in white polyethylene tubes to avoid heating and tubes were screwed to wooden pales and installed $1 \mathrm{~m}$ aboveground. A table tennis ball was placed into each funnel to prevent the sample from evaporating. According to IAEA standard procedures, samples were filled and stored in $2 \mathrm{~mL}$ brown glass vials covered by silicone septa (Mook, 2000).

Prior to field sampling the reliability of the table tennis ball to prevent evaporation losses was tested in the laboratory. During a $21 \mathrm{~d}$ period the effect of four different climatic conditions simulated in climate chambers $\left(30{ }^{\circ} \mathrm{C} / 15^{\circ} \mathrm{C}\right.$ and $15^{\circ} \mathrm{C} / 10^{\circ} \mathrm{C}$ in a $12 \mathrm{~h}$ day-night cycle each at 50 and $90 \%$ relative humidity) on the isotopic composition was tested. Collectors with table tennis balls were stored under these different climate conditions and water samples were withdrawn in intervals of three days. Even under the most unfavorable conditions in the climate chambers (temperature $30^{\circ} \mathrm{C} / 15^{\circ} \mathrm{C}$ and relative humidity $50 \%$ ), the enrichment of heavy isotopes was either not significant $(p>0.05)$ or, in the case of scenario 4 , within the measuring inaccuracy of the analytical device of $0.2 \%$ for $\delta^{18} \mathrm{O}$ and $0.6 \%$ for $\delta^{2} \mathrm{H}$ (Table 1). During the field experiment not more than one day passed between the precipitation event and sample collection. We therefore exclude a measurable effect of the sampling procedure on the isotopic compositions of the samples.

Total precipitation sums between each event sampling were also measured in the collectors. Climate data from stations near ECSF and El Tiro were also used to investigate the influence of climatic parameters - relative humidity (\%), air temperature $\left({ }^{\circ} \mathrm{C}\right)$, rainfall amount and intensity $\left(\mathrm{mm} \mathrm{h}^{-1}\right)$, and wind direction $\left(^{\circ}\right)$ and speed $\left(\mathrm{m} \mathrm{s}^{-1}\right)$ - on the isotopic composition of the samples (see Fig. 1). The wind direction of air masses moving over the study area was measured at El Tiro. In addition to the on-site climate measurements, we used the Hybrid Single-Particle Lagrangian Integrated Trajectory (HYSPLIT) model developed by Draxler and Rolph (2012) to calculate for each event the backward trajectories for the previous 12 days $(288 \mathrm{~h})$ of the air masses responsible for rainfall reaching the study area at an elevation of $1500 \mathrm{~m}$ a.g.l. (above ground level). For the analyses in our study, the HYSPLIT model was operated with meteorological input from the Global Data Assimilation System reanalysis data set. To account for interannual variability of climate conditions, we sampled in a period during which a shift in the prevailing wind conditions was most likely to occur (Emck, 2007). Therefore, samples were taken from September to December 2010.

\subsection{Analysis and statistics}

Isotope signatures of $\delta^{18} \mathrm{O}$ and $\delta^{2} \mathrm{H}$ were analyzed according to the IAEA standard procedure (Newman et al., 2009) using a Los Gatos Research DLT-100-Liquid Water Isotope Analyzer (Los Gatos Research Inc., Mountain View, US). Water samples are vaporized and analyzed via near infrared absorption spectroscopy to simultaneously quantify the $\delta^{18} \mathrm{O}$ and $\delta^{2} \mathrm{H}$ isotope signatures in an optical cell. Isotope ratios are reported in per mil $(\% \circ)$ relative to an internationally acknowledged reference standard, the Vienna Standard Mean Ocean Water or VSMOW (Craig, 1961b). Precision of the method is $0.2 \%$ o for $\delta^{18} \mathrm{O}$ and $0.6 \%$ for $\delta^{2} \mathrm{H}$, resulting in a quadratic error of $1.7 \%$ for deuterium excess (LGR, 2012).

Data preparation was conducted by excluding outliers from the repetitive measurements of $\delta^{18} \mathrm{O}$ and $\delta^{2} \mathrm{H}$. Results were considered as outliers if the standard deviation from the average was larger than one. Not more than one out of three samples per event and sampling point was allowed to be excluded. If two out of three results had a standard deviation larger than one, no outlier was excluded. On average the three samples per event and sampling point showed a fairly similar standard derivation of $0.27 \%$ for $\delta^{18} \mathrm{O}$ (ranging from 0.03 to $0.87 \%$ ) and $0.58 \%$ ofor $\delta^{2} \mathrm{H}$ (ranging from 0.01 to $1.66 \%$ ) for all four sites. Mean values of the remaining results built the data set from here on. All deviations are given as mean error. Statistical evaluation was performed using SPSS Statistics (Version 16.0; SPSS Inc. Chicago, IL, US). For a comparison of our results, isotope precipitation data from the IAEA-GNIP station Amaluza, Ecuador, was used (IAEA, 2012). Amaluza is located about $170 \mathrm{~km}$ north of the study area, and the data set comprises monthly means starting from May 1992-July 1994 (27 values). 
Table 2. Descriptive statistic of all 26 events sampled.

\begin{tabular}{llrrrr}
\hline & Location & Min. & Mean & Max. & Range \\
\hline$\delta^{2} \mathrm{H} \mathrm{[ \% o]}$ & All stations & -120.2 & -27.6 & 30.8 & 151.0 \\
& ECSF (1800 m a.s.1.) & -92.9 & -22.0 & 30.8 & 123.7 \\
& Chamusquin (2070 m a.s.1.) & -95.0 & -25.0 & 26.9 & 121.8 \\
& Navidade (2460 m a.s.1.) & -101.7 & -30.6 & 9.2 & 110.9 \\
& El Tiro (2800 m a.s.1.) & -120.2 & -32.9 & 14.0 & 134.2 \\
\hline$\delta^{18} \mathrm{O}[\%$ o] & All stations & -16.5 & -5.1 & 2.7 & 19.2 \\
& ECSF (1800 m a.s.1.) & -12.1 & -4.0 & 2.7 & 14.8 \\
& Chamusquin (2070 m a.s.1.) & -12.7 & -4.6 & 1.8 & 14.4 \\
& Navidade (2460 m a.s.l.) & -14.3 & -5.7 & -0.9 & 13.4 \\
& El Tiro (2800 m a.s.1.) & -16.5 & -6.1 & 0.1 & 16.5 \\
\hline
\end{tabular}

\section{Results and discussion}

In this study, 26 events were sampled at four altitudinal levels in a period from 2 September to 25 December 2010 (during all events we recorded precipitation at all four altitudes). Isotopic compositions of open rainfall range from -16.5 to $2.7 \%$ ofor $\delta^{18} \mathrm{O}$ and from -120.2 to $30.8 \%$ for $\delta^{2} \mathrm{H}$ (see Table 2 for more details). Compared to the study of Goller et al. (2005) and the data from Amaluza, isotope signatures presented in this study cover a relatively wide range. This fact can be attributed to the event-based sampling design where there is no mixing of events with extreme values, as compared to sampling in defined intervals which often produces a narrower range of values. The range is also in good agreement with the daily precipitation values reported by Villacís et al. (2008) for lower parts of the Ecuadorian Amazon in the northeast of the country, ranging from -15.51 to $1.56 \%$ for $\delta^{18} \mathrm{O}$.

In comparison to the global meteoric water line (GMWL; $\delta^{2} \mathrm{H}=8 \times \delta^{18} \mathrm{O}+10 \%$ o defined by Craig, 1961a, or more recently $\delta^{2} \mathrm{H}=8.13 \times \delta^{18} \mathrm{O}+10.8 \%$ defined by Rozanski et al., 1993) the local meteoric water line for all 26 events $\left(\delta^{2} \mathrm{H}=8.31 \times \delta^{18} \mathrm{O}+14.47 \%\right.$ ) shows a slightly higher slope, which is still in good agreement with the slope expected under equilibrium conditions represented by the GMWL. The higher intercept (deuterium excess) of the local meteoric water line is most likely attributable to re-evaporated/recycled precipitation reaching the study area during the investigation period. Figure 2a shows the $\delta^{18} \mathrm{O}$ isotope signatures of all sampled events $\left(\delta^{2} \mathrm{H}\right.$ shows the same course - data not shown; any difference between $\delta^{2} \mathrm{H}$ and $\delta^{18} \mathrm{O}$ is expressed by the deuterium excess shown in Fig. 2b). Spatial variability, i.e. the difference between the four sampling sites, is relatively low compared to the temporal variability, which points to a distinct dependency of isotope signatures on the prevailing weather conditions and the origin of the air masses.

\subsection{Altitude effect}

To separate the altitude effect from the temporal variation, the altitude effect was calculated for each event separately (Fig. 3). Event lapse rates ( $\delta$ versus altitude) calculated by linear regression show that the concentration of heavy isotopes in the precipitation samples generally decreases with altitude (Figs. 3 and 4). On average, the $\delta^{18} \mathrm{O}$ altitude effect is $-0.22 \% \circ \times 100 \mathrm{~m}^{-1}$, and for $\delta^{2} \mathrm{H}$ it amounts to $-1.12 \% \circ \times 100 \mathrm{~m}^{-1}$ (standard error $0.2 \% \circ$ for $\delta^{18} \mathrm{O}$ and 1.39 for $\delta^{2} \mathrm{H}$ ). As usual for tropical regions (Sturm et al., 2007), it lies within the lower part of the ranges reported in literature (Table 3). Most $\delta^{18} \mathrm{O}$ event lapse rates of the present study are between -0.1 and $-0.4 \% \circ \times 100 \mathrm{~m}^{-1}$ $\left(\delta^{2} \mathrm{H}:-0.8\right.$ to $\left.-1.5 \% \circ \times 100 \mathrm{~m}^{-1}\right)$. However, three out of 26 events do not show a negative lapse rate for both $\delta^{18} \mathrm{O}$ and $\delta^{2} \mathrm{H}$ (Fig. 4; dates 6 September, 1 October and 21 October). The ANOVA belonging to the overall linear regression of the data using all four stations showed that the altitude effect of $\delta^{18} \mathrm{O}$ is significant $(p<0.05)$, while for $\delta^{2} \mathrm{H}$ it is insignificant $(p=0.19)$. Nevertheless, using a one-tailed t-test, it could be shown that the event lapse rates deviate significantly from zero for both $\delta^{18} \mathrm{O}$ and $\delta^{2} \mathrm{H}(p<0.01)$. Consequently, we generally assume that concentrations of heavy isotopes decrease with altitude.

The deuterium excess also shows a significant spatial variability, i.e. an increase with altitude of $0.6 \% \circ \times 100 \mathrm{~m}^{-1}$ $(p<0.01)$ (Fig. 3). Gonfiantini et al. (2001) report that the increase of deuterium excess with altitude is predominantly present at high relative humidity, which is prevailing in the study area. However, there must be additional factors to explain the altitude effect of deuterium excess (Gat et al., 2000).

The assumed linearity of the altitude effect can be masked by weather conditions during which this normally prevailing linear effect is overruled and yields a non-linear response. However, the applied linear model has proven to predict the isotopic signature significantly well. The altitude effect within our data set is further superimposed by a temporal component expressed not only by a change in local 


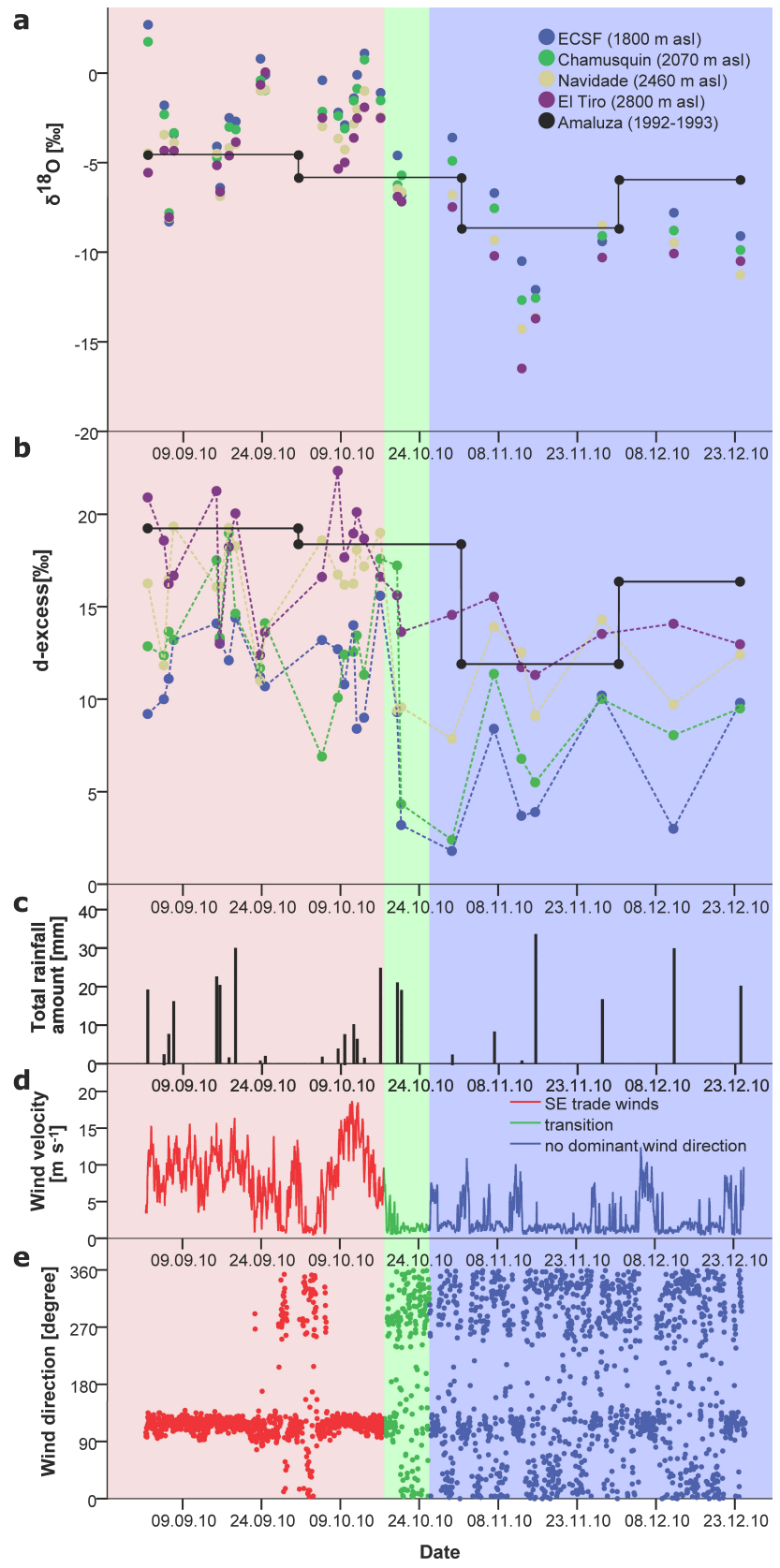

Fig. 2. Results of the 26 events sampled. (a) $\delta^{18} \mathrm{O}$ isotope signatures, (b) deuterium excess of all sampled events compared to weighted monthly means from GNIP station Amaluza from 19921993, (c) total amount of rainfall for each event, (d) wind velocity and (e) wind direction for the investigated period recorded at the El Tiro climate station. For (a) and (b) the different measurement stations are color coded. For (d) and (e) the colors indicate the 3 different climate periods.

climate parameters but also by the source of the prevailing air masses originating mostly from the Amazon or the Pacific (see Sect. 3.2), which further disguises the results of the linear regression.
In the studies presented by Gonfiantini et al. (2001) and Peng et al. (2010), a seasonality of the altitude effect is reported. Both studies were also carried out in tropical environments with a similar altitudinal air temperature gradient $\left(0.61{ }^{\circ} \mathrm{C} \times 100 \mathrm{~m}^{-1}\right.$ in our study area; Gonfiantini et al., 2001, $0.42-0.55^{\circ} \mathrm{C} \times 100 \mathrm{~m}^{-1}$; Peng et al., 2010, $\left.0.53-0.65^{\circ} \mathrm{C} \times 100 \mathrm{~m}^{-1}\right)$. The authors explain this by the larger lapse rate (temperature vertical gradient) during rainy months. During the investigation period, no such temporal effect on the altitude effect is observed in our study area. Furthermore, a multiple regression analysis of event lapse rates revealed no significant influence of temperature, relative humidity and precipitation amount or intensity on the altitude effect. However, one factor that might enhance the altitude effect is the so-called pseudo-altitude effect (Moser and Stichler, 1971), which leads to an evaporative enrichment of heavy isotopes in falling raindrops. Due to the larger altitudinal difference between cloud base and surface, this enrichment is more pronounced at lower altitudes (Gat et al., 2000), and can be almost excluded in tropical montane cloud forests where the cloud base is often at the same level as the sampling sites.

\subsection{Impact of prevailing air masses}

The temporal variability of isotope signatures in tropical precipitation is to a large degree attributed to the origin of air masses that prevail during different times of the year (Liu et al., 2007; Rhodes et al., 2006). Isotope signatures of precipitation in the study area are significantly higher during the times of SE trade winds (2 September-18 October) than for the rest of the investigation period (26 October24 December) with no clear wind direction and lower wind velocities (Fig. 2). Between these two periods a transition in the origin and consistence of the source of the prevailing air masses takes place (19-25 October). This transition phase at the end of the trade wind period is characterized by abating wind velocities and intermediate isotope signatures (Fig. 2d). Concentrations of $\delta^{18} \mathrm{O}$ range between -8.3 to $+2.7 \%$ for trade wind-related events, -7.2 to $-4.6 \%$ o for events during the transition phase, and -16.5 to $-3.6 \%$ for other events $\left(\delta^{2} \mathrm{H}:-55.3\right.$ to $30.8 \%,-51.2$ to $-27.5 \%$, and -120.2 to $-27.0 \%$, respectively). Mean values of $\delta^{18} \mathrm{O}$ are $-3.0 \%$ for trade wind-related precipitation, $-6.3 \%$ for events during the transition phase and $-9.9 \%$ for other precipitation events $\left(\delta^{2} \mathrm{H}:-8.8,-40.3\right.$ and $-69.5 \%$ ) $)$.

All three periods represent a distinct weather period. Before 18 October local climate measurements at the El Tiro climate station showed $91 \%$ east to southeasterly winds and average wind velocities of $9.2 \mathrm{~m} \mathrm{~s}^{-1}$, and thereafter, only $32 \%$ and average wind velocities of $2.5 \mathrm{~m} \mathrm{~s}^{-1}$ (26 October24 December). The high wind speed and steady wind direction of the first period are typical for trade wind-dominated periods. Without the SE trade winds, the period after the 26 October shows no dominant wind direction. The transition 


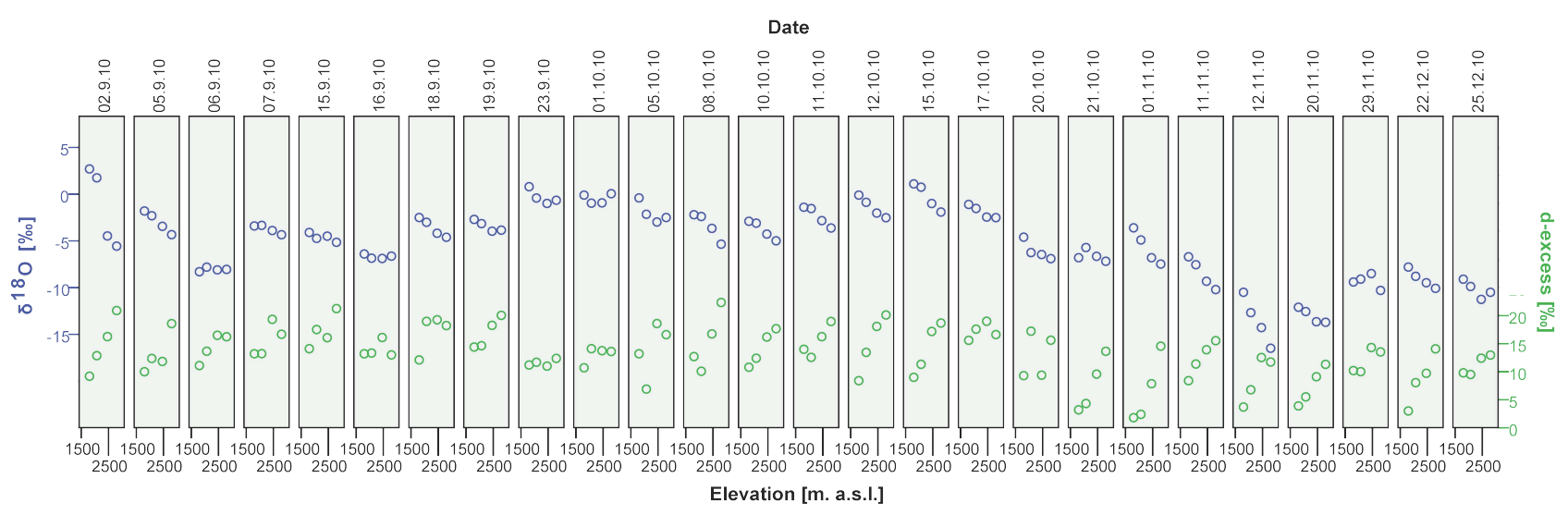

Fig. 3. Altitude effect and temporal variation of $\delta^{18} \mathrm{O}$ isotope signature and the deuterium excess in precipitation.

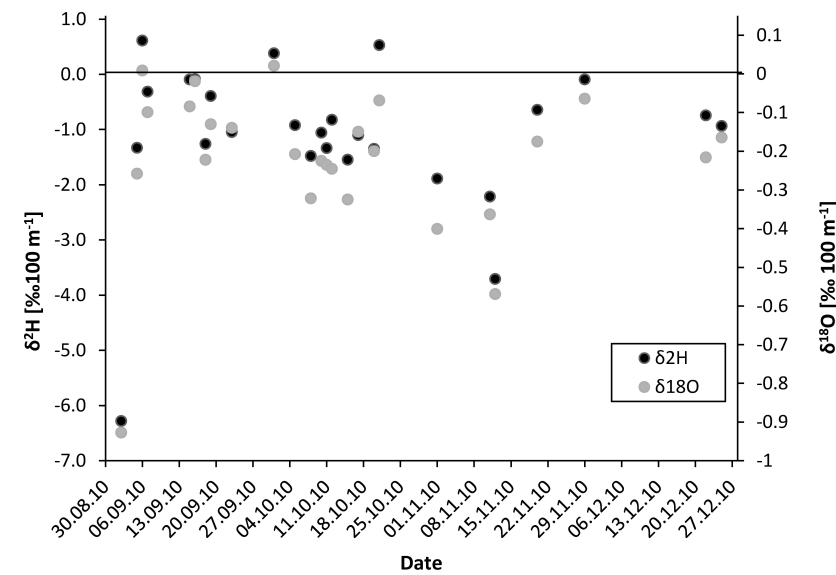

Fig. 4. Event-based altitude effect of $\delta^{18} \mathrm{O}$ and $\delta^{2} \mathrm{H}$ isotope signatures in precipitation. The majority of the events show a depletion of heavy isotopes with altitude (i.e. a negative lapse rate). Only during 3 events for ${ }^{2} \mathrm{H}$ and 2 events for ${ }^{18} \mathrm{O}$ out of 26 events was an enrichment of heavy isotopes with altitude recorded.

phase is characterized by the lowest wind velocities of $1.3 \mathrm{~m} \mathrm{~s}^{-1}$ on average and no clear wind direction. HYSPLIT results (Fig. 5) confirmed the different sources of the air masses. In the first phase of the investigation period, all monitored rain events passed with the trade winds over the Amazon region. During the transition phase the air parcels responsible for the recorded precipitation traveled for over 12 days across the Amazon region close to the study area with a relative low velocity. This potentially indicates that the arriving air masses become continuously depleted in heavy isotopes in the course of ongoing rainfall events before reaching the study area. After mid-October the backward trajectories show no clear pattern delivering moisture to the study area from the Pacific as well as from the Gulf of Mexico and the Amazon (Fig. 5).

Since most of the precipitation in the study area is trade wind-related orographic precipitation, which is the main

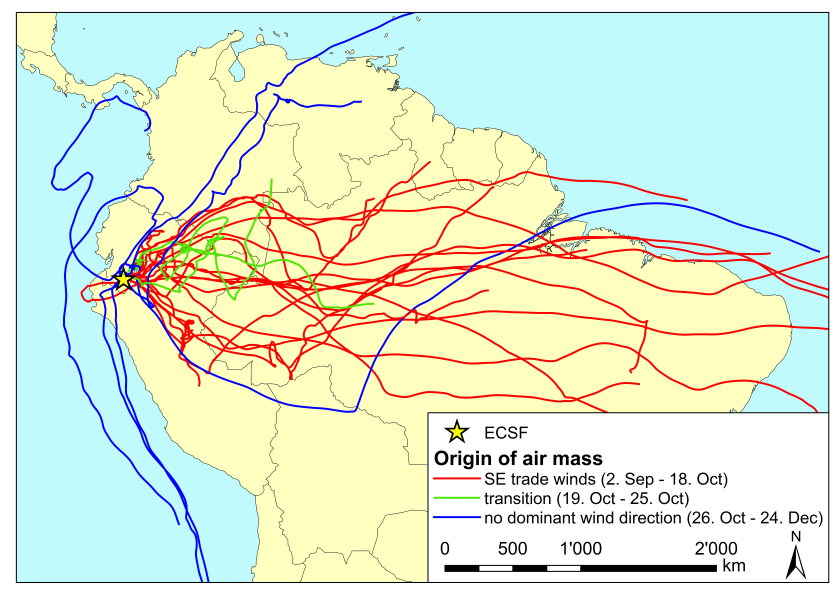

Fig. 5. 12 days back trajectories for the 26 rain events calculated with the Hybrid Single-Particle Lagrangian Integrated Trajectory (HYSPLIT) model developed by Draxler and Rolph (2012).

driving factor behind the observed altitude effect, it is important to understand the impact of trade winds on the isotopic composition of precipitation in the study area. Tropical trade winds move at altitudes below $3000 \mathrm{~m}$ a.s.l. and take up large amounts of recycled moisture over the Amazon Basin when coming from the SE. This moisture is enriched in heavy isotopes and shows a higher deuterium excess due to the discrimination of heavy isotopes during fractionation processes like evaporation. Reaching the Andes, the air masses are orographically lifted and thus subject to rainout (Scholl et al., 2002). Thus, trade wind-related precipitation in the study area is enriched in heavy isotopes. From mid-October to the end of December, when trade winds weaken, other air masses, partly originating from the Pacific, influence the climate in the investigated area (Fig. 5, Bendix et al., 2008; Emck, 2007), and precipitation contains significantly fewer heavy isotopes. Despite being of orographic nature as well, this precipitation is not characterized by recycled moisture. 
Table 3. Altitude effect of $\delta^{2} \mathrm{H}$ and $\delta^{18} \mathrm{O}$ in precipitation from various sites around the world.

\begin{tabular}{llll}
\hline Author & $\delta^{2} \mathrm{H}$ & $\begin{array}{l}\delta^{18} \mathrm{O} \\
{\left[\% \circ \times 100 \mathrm{~m}^{-1}\right]} \\
{\left[\% \circ \times 100 \mathrm{~m}^{-1}\right]}\end{array}$ & Location \\
\hline Yurtsever and Gat (1981) & -1.5 to -4 & -0.15 to -0.5 & GNIP data, worldwide \\
Gonfiantini et al. (2001) & - & -0.15 to -0.24 & Mount Cameroon, Bolivia \\
Scholl et al. (2009) & -0.6 & -0.12 & Cloud forest, Puerto Rico \\
Peng et al. (2010) & - & -0.17 to -0.22 & Taiwan \\
Garcia et al. (1998) & - & -0.17 & Ecuador \\
Siegenthaler and Oeschger (1980) & - & -0.25 & Switzerland $(<2000 \mathrm{~m})$ \\
Siegenthaler and Oeschger (1980) & - & -0.09 & Switzerland $(>2000 \mathrm{~m})$ \\
Hou et al. (2003) & - & -0.12 to -0.29 & Himalaya \\
McGuire et al. (2005) & - & -0.15 & Oregon, USA \\
Aravena et al. (1999) & - & -1 & Chile \\
Saylor et al. (2009) & -1.5 & -0.18 & Colombia \\
Cortés et al. (1997) & - & -0.2 & Mexico \\
Vogel et al. (1975) & - & -0.1 to -0.6 & Argentina \\
Kattan (2006) & -1.1 & -0.14 & Syria \\
Vimeux et al. (2005) & -1.7 & - & Bolivia \\
Vimeux et al. (2011) & -1.5 & - & Bolivia, event-based \\
This study & -1.12 & -0.22 & Ecuador, event-based \\
\hline
\end{tabular}

To further investigate and strengthen our assumption that recycled moisture from the Amazon Basin is causing the high isotopic composition during trade wind-related precipitation events, we used the deuterium excess parameter to assess the actual amount of recycled moisture (Araguas-Araguas et al., 2000; Bowen and Revenaugh, 2003; Froehlich et al., 2002; Gat, 2000; Liu et al., 2007; Njitchoua et al., 1999; Peng et al., 2010; Victoria et al., 1991). For trade wind-related precipitation events, deuterium excess averages $14.9 \%$ and hence, is significantly higher than for other events $(d=9.6 \%$ o). The temporal variability of event deuterium excess in the study area shows a similar trend compared to the $\delta^{18} \mathrm{O}$ and $\delta^{2} \mathrm{H}$ values, including the decrease after mid-October (Fig. 2b). These observations confirm the assumption that intense moisture recycling takes place when precipitation is attributed to SE trade winds. Goller et al. (2005) report an annual mean deuterium excess of $11.1 \%$ for their site at the lower part of the same investigation area, pointing to the assumption that moisture recycling might not be high all year long. Since they did not measure both $\delta^{2} \mathrm{H}$ and $\delta^{18} \mathrm{O}$ for all samples, no temporal variability of deuterium excess was reported. Mean annual deuterium excess at the GNIP station Amaluza was $15.5 \%$. Highest values were measured from July to October (18.4 to $19.2 \%$ o), i.e. the time of the year when SE trade winds prevail in the study area. Lowest values were measured from March to May (10 to $12.5 \%$ ) and in November $(11.9 \%$ ).

Some studies report an amount effect (Bony et al., 2008) or a seasonality (Henderson-Sellers et al., 2010; Liu et al., 2007; Rhodes et al., 2006) of deuterium excess, showing higher values during the dry season. For the present study, a linear regression of event deuterium excess with precipitation amount showed no significant influence $(p=0.56)$. The temporal variability therefore should, analogously to the $\delta^{18} \mathrm{O}$ and $\delta^{2} \mathrm{H}$ values, rather be attributed to the influence of SE trade winds bringing precipitation to the study area that contains large amounts of recycled moisture.

\section{Conclusions}

The stable isotopic composition of precipitation collected in the San Francisco catchment showed strong temporal variations consistent with differences in weather conditions and the origin of air masses. Elevated deuterium excess values indicate that recycled moisture from the Amazon Basin is an important flux for orographic precipitation attributed to southeasterly trade winds. Rainfalls following these trade winds are enriched in heavy isotopes compared to precipitation during other weather conditions. We further found decreasing concentrations of heavy isotopes with altitude.

In general, the presented findings are in good agreement with the underlying theoretical concepts and have highlighted the need to account for spatial and temporal variation. Comparison to studies conducted in the same research area and in comparable ecosystems showed that the variability of the isotopic composition in the study area is rather governed by the prevailing air masses than by a local amount effect due to rainout. As in the case of the altitude effect, any on site amount effect is overshadowed by the temporal variability. Calculations were therefore conducted separately for the different wind conditions (SE trade winds, transition phase and post-trade wind period with no clear wind direction), but still revealed no significant effect. However, longer term measurements will be needed to rule out the impact of the 
amount effect, and of other air masses with certainty (particularly NE trade winds that prevail in the study area from January to March). Especially in a region marked by the influence of El Niño/La Niña processes, it will be important to account for the interannual variability of the isotopic signature of the rainfall to further strengthen and underline the drawn conclusions.

The presented findings build a solid base showing the range of the spatial, temporal variability of isotopic composition in the study area. Though the monitoring period was relatively short, the extensive monitoring set-up captured the complete range of climate conditions within the study area (e.g. trade winds and precipitation patterns) on a fine temporal and spatial scale. In combination with the long-term monitoring currently conducted at ECSF, further insight will be gained about interannual variability (Vimeux et al., 2011) and the effect of El Niño and La Niña on the isotopic signature of the incoming precipitation in the study area.

Combining seasonal and spatial variations of $\delta$ and deuterium excess can provide an effective tool for tracing moisture through the hydrological cycle. Further work will use these data to validate hydrological models identifying the actual pathways of the water in the catchment and calculate mean transit times. Moreover, the data can serve as a contribution to the global data set on isotopic composition of precipitation, which is used in climate modeling.

Acknowledgements. The authors gratefully acknowledge the NOAA Air Resources Laboratory for the provision of the HYSPLIT transport model. We would further like to thank the DFG for generous funding of this project (BR2238/4-2) in the frame of the Research Unit FOR816 (www.tropicalmountainforest.org).

Edited by: S. Archfield

\section{References}

Araguas-Araguas, L., Froehlich, K., and Rozanski, K.: Deuterium and oxygen-18 isotope composition of precipitation and atmospheric moisture, Hydrol. Process., 14, 1341-1355, 2000.

Aravena, R., Suzuki, O., Pena, H., Pollastri, A., Fuenzalida, H., and Grilli, A.: Isotopic composition and origin of the precipitation in Northern Chile, Appl. Geochem., 14, 411-422, 1999.

Barthold, F. K., Tyralla, C., Schneider, K., Vache, K. B., Frede, H.G., and Breuer, L.: How many tracers do we need for end member mixing analysis (EMMA)? A sensitivity analysis, Water Resour. Res., 47, W08519, doi:10.1029/2011WR010604, 2011.

Bendix, J., Homeier, J., Cueva Ortiz, E., Emck, P., Breckle, S.-W., Richter, M., and Beck, E.: Seasonality of weather and tree phenology in a tropical evergreen mountain rain forest, Int. J. Biometeorol., 50, 370-384, doi:10.1007/s00484-006-0029-8, 2006.

Bendix, J., Rollenbeck, R., Richter, M., Fabian, P., and Emck, P.: Climate, in: Gradients in a Tropical Mountain Ecosystem of Ecuador, edited by: Beck, E., Bendix, J., Kottke, I., Makeschin, F., and Mosandl, R., Springer, Berlin, 63-73, 2008.
Birkel, C., Dunn, S. M., Tetzlaff, D., and Soulsby, C.: Assessing the added value of high-resolution isotope tracer data in rainfallrunoff modelling, Hydrol. Earth Syst. Sci. Discuss., 6, 62076246, doi:10.5194/hessd-6-6207-2009, 2009.

Bony, S., Risi, C., and Vimeux, F.: Influence of convective processes on the isotopic composition $\left(\delta^{18} \mathrm{O}\right.$ and $\left.\delta \mathrm{D}\right)$ of precipitation and water vapor in the tropics: 1. Radiativeconvective equilibrium and Tropical Ocean-Global AtmosphereCoupled Ocean-Atmosphere Response Experiment (TOGACOARE) simulations, J. Geophys. Res., 113, D19305, doi:10.1029/2008JD009942, 2008.

Bowen, G. J. and Revenaugh, J.: Interpolating the isotopic composition of modern meteoric precipitation, Water Resour. Res., 39, 1299, doi:10.1029/2003WR002086, 2003.

Breitenbach, S. F. M., Adkins, J. F., Meyer, H., Marwan, N., Kumar, K. K., and Haug, G. H.: Strong influence of water vapor source dynamics on stable isotopes in precipitation observed in Southern Meghalaya, NE India, Earth Planet. Sc. Lett., 292, 212-220, doi:10.1016/j.eps1.2010.01.038, 2010.

Bücker, A., Crespo, P., Frede, H.-G., Vaché, K., Cisneros, F., Breuer, L.: Identifying Controls on Water Chemistry of Tropical Cloud Forest Catchments: Combining Descriptive Approaches and Multivariate Analysis, Aquat. Geochem., 16, 127-149, 2010.

Cortés, A., Durazo, J., and Farvolden, R. N.: Studies of isotopic hydrology of the basin of Mexico and vicinity: annotated bibliography and interpretation, J. Hydrol., 198, 346-376, doi:10.1016/S0022-1694(96)03273-8, 1997.

Craig, H.: Isotopic variations in meteoric waters, Science, 133, 1702-1703, doi:10.1126/science.133.3465.1702, 1961a.

Craig, H.: Standard for reporting concentrations of deuterium and oxygen-18 in natural waters, Science, 133, 1833-1834, doi:10.1126/science.133.3467.1833, 1961 b.

Crespo, P., Bücker, A., Feyen, J., Vaché, K. B., Frede, H., and Breuer, L.: Preliminary evaluation of the runoff processes in a remote montane cloud forest basin using Mixing Model Analysis and Mean Transit Time, Hydrol. Process., 26, 3896-3910, doi:10.1002/hyp.8382, 2012.

Dansgaard, W.: Stable isotopes in precipitation, Tellus, 16, 436468, 1964.

Darling, W. G. and Talbot, J. C.: The O and $\mathrm{H}$ stable isotope composition of freshwaters in the British Isles. 1. Rainfall, Hydrol. Earth Syst. Sci., 7, 163-181, doi:10.5194/hess-7-163-2003, 2003.

Draxler, R. R. and Rolph, G. D.: HYSPLIT (HYbrid SingleParticle Lagrangian Integrated Trajectory) Model, access via NOAA ARL READY website: http://ready.arl.noaa.gov/ HYSPLIT.php, last access: 27 September 2012, NOAA Air Resources Laboratory, Silver Spring, MD, 2012.

Emck, P.: A climatology of south Ecuador - with special focus on the major Andean ridge as Atlantic-Pacific climate divide, Friedrich-Alexander-Universität, Erlangen-Nürnberg, 2007.

Emck, P. and Richter, M.: An Upper Threshold of Enhanced Global Shortwave Irradiance in the Troposphere Derived from Field Measurements in Tropical Mountains, J. Appl. Meteorol. Clim., 47, 2828-2845, doi:10.1175/2008JAMC1861.1, 2008.

Feng, X., Faiia, A. M., and Posmentier, E. S.: Seasonality of isotopes in precipitation: A global perspective, J. Geophys. Res., 114, D08116, doi:10.1029/2008JD011279, 2009. 
Froehlich, K., Gibson, J. J., and Aggarwal, P.: Deuterium excess in precipitation and its climatological significance, in: Study of Environmental Change Using Isotope Techniques, International Atomic Energy Agency, Vienna, 54-66, 2002.

Garcia, M., Villalba, F., Araguas-Araguas, L., and Rozanski, K.: The role of atmospheric circulation patterns in controlling the regional distribution of stable isotope contents in precipitation: Preliminary results from two transects in the Ecuadorian Andes, in: Isotope Techniques in the Study of Environmental Change, International Atomic Energy Agency, Vienna, 127-140, 1998.

Garvelmann, J., Külls, C., and Weiler, M.: A porewater-based stable isotope approach for the investigation of subsurface hydrological processes, Hydrol. Earth Syst. Sci., 16, 631-640, doi:10.5194/hess-16-631-2012, 2012.

Gat, J. R.: Oxygen and hydrogen isotopes in the hydrologic cycle, Annu. Rev. Earth Planet Sci., 24, 225-262, doi:10.1146/annurev.earth.24.1.225, 1996.

Gat, J. R.: Atmospheric water balance - the isotopic perspective, Hydrol. Process., 14, 1357-1369, 2000.

Gat, J. R., Mook, W. G. and Meijer, H.: Environmental isotopes in the hydrological cycle, in: Vol. II Atmospheric Water, edited by: Mook, W., International Atomic Energy Agency, Groningen, 2000.

Göttlicher, D., Obregón, A., Homeier, J., Rollenbeck, R., Nauss, T., and Bendix, J.: Land-cover classification in the Andes of southern Ecuador using Landsat ETM+ data as a basis for SVAT modelling, Int. J. Remote Sens., 30, 1867-1886, doi:10.1080/01431160802541531, 2009.

Goller, R., Wilcke, W., Leng, M. J., Tobschall, H. J., Wagner, K., Valarezo, C., and Zech, W.: Tracing water paths through small catchments under a tropical montane rain forest in south Ecuador by an oxygen isotope approach, J. Hydrol., 308, 67-80, doi:10.1016/j.jhydrol.2004.10.022, 2005.

Gonfiantini, R., Roche, M.-A., Olivry, J.-C., Fontes, J.-C., and Zuppi, G. M.: The altitude effect on the isotopic composition of tropical rains, Chem. Geol., 181, 147-167, doi:10.1016/S00092541(01)00279-0, 2001.

Henderson-Sellers, A., McGuffie, K., and Zhang, H.: Stable isotopes as validation tools for global climate model predictions of the impact of Amazonian deforestation, J. Climate, 15, 26642677, 2002.

Hou, S., Masson-Delmotte, V., Qin, D., and Jouzel, J.,: Modern precipitation stable isotope vs. elevation gradients in the High Himalaya. Comment on "A new approach to stable isotopebased paleoaltimetry: implications for paleoaltimetry and paleohypsometry of the High Himalaya since the Late Miocene" by David B. Rowley et al. [Earth Planet. Sci. Lett. 188 (2001) 253268], Earth Planet. Sc. Lett., 209, 395-399, doi:10.1016/S0012821X(03)00043-8, 2003.

IAEA: Water Resources Programme - Global Network of Isotopes in Precipitation: http://www-naweb.iaea.org/napc/ih/IHS resources_gnip.html, last access: 10 February 2012.

Kabeya, N., Katsuyama, M., Kawasaki, M., Ohte, N., and Sugimoto, A.: Estimation of mean residence times of subsurface waters using seasonal variation in deuterium excess in a small headwater catchment in Japan, Hydrol. Process., 21, 308-322, doi:10.1002/hyp.6231, 2007.
Kattan, Z.: Characterization of surface water and groundwater in the Damascus Ghotta basin: hydrochemical and environmental isotopes approaches, Environ. Geol., 51, 173-201, doi:10.1007/s00254-006-0316-z, 2006.

Kebede, S. and Travi, Y.: Origin of the $\delta^{18} \mathrm{O}$ and $\delta^{2} \mathrm{H}$ composition of meteoric waters in Ethiopia, Quatern. Int., 257, 4-12, doi:10.1016/j.quaint.2011.09.032, 2011.

Koivusalo, H., Karvonen, T., and Lepistö, A.: A quasi-threedimensional model for predicting rainfall-runoff processes in a forested catchment in Southern Finland, Hydrol. Earth Syst. Sci., 4, 65-78, doi:10.5194/hess-4-65-2000, 2000.

Lachniet, M. S. and Patterson, W. P.: Use of correlation and stepwise regression to evaluate physical controls on the stable isotope values of Panamanian rain and surface waters, J. Hydrol., 324, 115-140, doi:10.1016/j.jhydrol.2005.09.018, 2006.

Lachniet, M. S. and Patterson, W. P.: Oxygen isotope values of precipitation and surface waters in northern Central America (Belize and Guatemala) are dominated by temperature and amount effects, Earth Planet. Sc. Lett., 284, 435-446, doi:10.1016/j.eps1.2009.05.010, 2009.

Lee, J. E., Johnson, K., and Fung, I.: Precipitation over South America during the Last Glacial Maximum: An analysis of the "amount effect" with a water isotope-enabled general circulation model, Geophys. Res. Lett., 36, L19701, doi:10.1029/2009GL039265, 2009.

LGR: Los Gatos Research: http://www.lgrinc.com/, last access: 10 April 2012.

Liebminger, A., Haberhauer, G., Papesch, W., and Heiss, G.: Footprints of climate in groundwater and precipitation, Hydrol. Earth Syst. Sci., 11, 785-791, doi:10.5194/hess-11-785-2007, 2007.

Liu, W. J., Liu, W. Y., Li, P. J., Gao, L., Shen, Y. X., Wang, P. Y., Zhang, Y. P., and Li, H. M.: Using stable isotopes to determine sources of fog drip in a tropical seasonal rain forest of Xishuangbanna, SW China, Agr. Forest Meteorol., 143, 80-91, doi:10.1016/j.agrformet.2006.11.009, 2007.

Martinelli, L. A., Victoria, R. L., Silveira Lobo Sternberg, L., Ribeiro, A., and Zacharias Moreira, M.: Using stable isotopes to determine sources of evaporated water to the atmosphere in the Amazon basin, J. Hydrol., 183, 191-204, doi:10.1016/00221694(95)02974-5, 1996.

McGuire, K., DeWalle, D., and Gburek, W.: Evaluation of mean residence time in subsurface waters using oxygen-18 fluctuations during drought conditions in the mid-Appalachians, J. Hydrol., 261, 132-149, doi:10.1016/S0022-1694(02)00006-9, 2002.

McGuire, K. J., McDonnell, J. J., Weiler, M., Kendall, C., McGlynn, B. L., Welker, J. M., and Seibert, J.: The role of topography on catchment-scale water residence time, Water Resour. Res., 41, W05002, doi:10.1029/2004WR003657, 2005.

Mook, W. G.: Environmental isotopes in the hydrological cycle, in: Vol. I Introduction, edited by: Mook, W. G., International Atomic Energy Agency, Groningen, 2000.

Moser, H. and Stichler, W.: Die Verwendung des Deuterium und Sauerstoff-18 Gehalts bei Hydrologischen Untersuchungen, Geol. Bavarica, 64, 7-35, 1971.

Newman, B., Tanweer, A. and Kurttas, T.: IAEA Standard Operating Procedure for the Liquid-Water Stable Isotope Analyser: http://www-naweb.iaea.org/napc/ih/documents/other/laser procedure_rev12.PDF (last access: 10 April 2012), 2009. 
Njitchoua, R., Sigha-Nkamdjou, L., Dever, L., Marlin, C., Sighomnou, D., and Nia, P.: Variations of the stable isotopic compositions of rainfall events from the Cameroon rain forest, Central Africa, J. Hydrol., 223, 17-26, doi:10.1016/S00221694(99)00087-6, 1999.

Peng, T.-R., Wang, C.-H., Huang, C.-C., Fei, L.-Y., Chen, C.-T. A., and Hwong, J.-L.: Stable isotopic characteristic of Taiwan's precipitation: A case study of western Pacific monsoon region, Earth Planet. Sc. Lett., 289, 357-366, doi:10.1016/j.eps1.2009.11.024, 2010.

Rhodes, A. L., Guswa, A. J., and Newell, S. E.: Seasonal variation in the stable isotopic composition of precipitation in the tropical montane forests of Monteverde, Costa Rica, Water Resour. Res., 42, W11402, doi:10.1029/2005WR004535, 2006.

Rietti-Shati, M., Yam, R., Karlen, W., and Shemesh, A.: Stable isotope composition of tropical high-altitude fresh-waters on Mt. Kenya, Equatorial East Africa, Chem. Geol., 166, 341-350, doi:10.1016/S0009-2541(99)00233-8, 2000.

Risi, C., Bony, S., and Vimeux, F.: Influence of convective processes on the isotopic composition $\left(\delta^{18} \mathrm{O}\right.$ and $\left.\delta \mathrm{D}\right)$ of precipitation and water vapor in the tropics: 2. Physical interpretation of the amount effect, J. Geophys. Res., 113, D19306, doi:10.1029/2008JD009943, 2008a.

Risi, C., Bony, S., Vimeux, F., Descroix, L., Ibrahim, B., Lebreton, E., Mamadou, I., and Sultan, B.: What controls the isotopic composition of the African monsoon precipitation? Insights from event-based precipitation collected during the 2006 AMMA field campaign, Geophys. Res. Lett., 35, L24808, doi:10.1029/2008GL035920, 2008b.

Rodgers, P., Soulsby, C., and Waldron, S.: Stable isotope tracers as diagnostic tools in upscaling flow path understanding and residence time estimates in a mountainous mesoscale catchment, Hydrol. Process., 19, 2291-2307, doi:10.1002/hyp.5677, 2005a.

Rodgers, P., Soulsby, C., Waldron, S., and Tetzlaff, D.: Using stable isotope tracers to assess hydrological flow paths, residence times and landscape influences in a nested mesoscale catchment, Hydrol. Earth Syst. Sci., 9, 139-155, doi:10.5194/hess-9-139-2005, 2005 b.

Rollenbeck, R. and Bendix, J.: Rainfall distribution in the Andes of southern Ecuador derived from blending weather radar data and meteorological field observations, Atmos. Res., 99, 277-289, doi:10.1016/j.atmosres.2010.10.018, 2011.

Rollenbeck, R., Bendix, J., and Fabian, P.: Spatial and temporal dynamics of atmospheric water inputs in tropical mountain forests of South Ecuador, Hydrol. Process., 25, 344-352, doi:10.1002/hyp.7799, 2011.

Rozanski, K., Araguás-Araguás, L., and Gonfiantini, R.: Relation between long-term trends of oxygen-18 isotope composition of precipitation and climate, Science, 258, 981-985, doi:10.1126/science.258.5084.981, 1992.

Rozanski, K., Araguás-Araguás, L., and Gonfiantini, R.: Isotopic patterns in modern global precipitation, Geophys. Monogr. Ser., 78, 1-36, doi:10.1029/GM078p0001, 1993.

Salati, E., Dall'Olio, A., Matsui, E., and Gat, J. R.: Recycling of water in the Amazon basin: an isotopic study, Water Resour. Res., 15, 1250-1258, doi:10.1029/WR015i005p01250, 1979.
Saylor, J. E., Mora, A., Horton, B. K., and Nie, J.: Controls on the isotopic composition of surface water and precipitation in the Northern Andes, Colombian Eastern Cordillera, Geochim. Cosmochim. Acta, 73, 6999-7018, doi:10.1016/j.gca.2009.08.030, 2009.

Scholl, M. A., Gingerich, S. B., and Tribble, G. W.: The influence of microclimates and fog on stable isotope signatures used in interpretation of regional hydrology: East Maui, Hawaii, J. Hydrol., 264, 170-184, doi:10.1016/S0022-1694(02)00073-2, 2002.

Scholl, M. A., Shanley, J. B., Zegarra, J. P., and Coplen, T. B.: The stable isotope amount effect: new insights from NEXRAD echo tops, Luquillo Mountains, Puerto Rico, Water Resour. Res., 45, W12407, doi:10.1029/2008WR007515, 2009.

Scholl, M. A., Eugster, W., and Burkard, R.: Understanding the role of fog in forest hydrology: stable isotopes as tools for determining input and partitioning of cloud water in montane forests, Hydrol. Process., 25, 353-366, doi:10.1002/hyp.7762, 2011.

Siegenthaler, U. and Oeschger, H.: Correlation of ${ }^{18} \mathrm{O}$ in precipitation with temperature and altitude, Nature, 285, 314-317, doi:10.1038/285314a0, 1980.

Sturm, C., Hoffmann, G., and Langmann, B.: Simulation of the stable water isotopes in precipitation over South America: Comparing regional to global circulation models, J. Climate, 20, 37303750, doi:10.1175/JCLI4194.1, 2007.

Valletcoulomb, C., Gasse, F., and Sonzogni, C.: Seasonal evolution of the isotopic composition of atmospheric water vapour above a tropical lake: Deuterium excess and implication for water recycling, Geochim. Cosmochim. Acta, 72, 4661-4674, doi:10.1016/j.gca.2008.06.025, 2008.

Victoria, R. L., Martinelli, L. A., Mortatti, J., and Richey, J.: Mechanisms of Water Recycling in the Amazon Basin: Isotopic Insights, Ambio, 20, 384-387, 1991.

Villacís, M., Vimeux, F., and Taupin, J. D.: Analysis of the climate controls on the isotopic composition of precipitation $\left(\delta^{18} \mathrm{O}\right)$ at Nuevo Rocafuerte, $74.5^{\circ} \mathrm{W}, 0.9^{\circ} \mathrm{S}, 250 \mathrm{~m}$, Ecuador, C. R. Geosci., 340, 1-9, doi:10.1016/j.crte.2007.11.003, 2008.

Vimeux, F., Gallaire, R., Bony, S., Hoffmann, G., and Chiang, J. C. H.: What are the climate controls on $\delta \mathrm{D}$ in precipitation in the Zongo Valley (Bolivia)? Implications for the Illimani ice core interpretation, Earth Planet. Sc. Lett., 240, 205-220, doi:10.1016/j.eps1.2005.09.031, 2005.

Vimeux, F., Tremoy, G., Risi, C., and Gallaire, R.: A strong control of the South American SeeSaw on the intra-seasonal variability of the isotopic composition of precipitation in the Bolivian Andes, Earth Planet. Sc. Lett., 307, 47-58, doi:10.1016/j.eps1.2011.04.031, 2011.

Vogel, J. C., Lerman, J. C., and Mook, W. G.: Natural isotopes in surface and groundwater from Argentina, Hydrol. Sci. Bull., 20, 203-221, 1975.

Yurtsever, Y. and Gat, J. R.: Atmospheric waters, in: Stable isotope hydrology, edited by: Gat, J. R. and Gonfiantini, R., IAEA Tech. Rep. Ser. 210, IAEA, Vienna, 1981. 